\title{
Development Path of Finance Major in Colleges and Universities
}

\author{
Wang Xiaoyu \\ Jiangxi College Of Foreign Studies
}

\begin{abstract}
Finance has already become one of the most popular majors in recent years, and many colleges and universities have especially set finance major to cultivate talents in this field. However, in recent years, there is a structural imbalance between demands for this major and supply of finance talents in colleges and universities, which on one hand is because enterprises lack talents, and on the other hand due to the difficulties for college students to find a job. Colleges and universities should focus on cultivating talents, and cultivating a person' $s$ quality is especially important. With the deepening of internationalization, this paper introduces the main contents of finance majors and international finance talents, the combination of ideological education and cultivating international finance talents as well as the structure to define international finance majors.
\end{abstract}

Keywords-Finance; Finance major; Talents; Development mode

\section{INTRODUCTION}

With the establishment and improvement of the socialist market economic system, each employer has generated new changes in their demand for talent, especially for Economics and Management (Finance) class graduates pay more attention to its overall quality, emphasize students' communication skills and solve practical solving skills. Because the talent has always been one of the main driving force of development, which for university personnel training presents new challenges, explore and seize new talent training model of a new era of reform and the road need to be resolved.

In recent years, the education level of commitment to gradually increase the range of subjects covered is increasing. Vocational education is an important part of our education system, it has a certain practicality by cultivating talents to engage in community development activities. Finance professional theoretical and practical application is stronger than an applied economics discipline, its high requirements for students, financial professionals built on top of the traditional theory of learning, through scientific and reasonable continuous improvement of practice teaching students the overall level of learning, enhanced ability to adapt to social development. Financial professional teaching more from hands-on practical aspects and links to strengthen students' education, promoting student better growth, and contribute to social development.

This paper mainly analyzes finance majors in colleges and universities from practical teaching design in a bid to cultivate finance talents better.

\section{SOCIAL SIGNIFICANCE OF FINANCIAL DEVELOPMENT}

Ever since the 20th century, with the rapid development of economy, the society as well as science and technology, whether in the further integration of the EU or the economic cooperation between G20, the borderless economy has already become an inevitable topic at this moment. As the world' s first industrialized country, the UK has already focused its attention on new fields and the financial field now. London and New York have already become the world' $s$ two international financial centers and are constantly expanding and attracting investment, so they are very important components in the economy of America and the UK.

Previously before Hong Kong, Shanghai was once an international financial center in the Far East, and due to domestic policy, the development of Shanghai's some lag compared with developed countries, but because of the internationalization of economic globalization has brought financial and Shanghai during the "five-second" promulgated the "Shanghai financial sector" second five "talent development plan" clearly in the "five-second" 
period, Shanghai will adhere to international financial talent team construction, financial professionals market allocation of resources, social services financial talent as well as financial and scientific talent management, speed up financial team building talents. Economic globalization provides an opportunity for our country to learn from the operational experience of developed country markets, help China become familiar with and adapt to the operating rules of the market economy, promoting the socialist market economic system continues to improve, accelerate the improvement and development of China's talent market.

Nowadays, it has been universally recognized that talent is the primary factor in economy. Economic globalization has already become the trend of global economic development, and economic development has become a nation' s core interest. China, while in the transition period, must effectively utilize and allocate talent resources faced with the challenge from intelligent economy so as to improve China's comprehensive strength.

\section{Problems In Finance Majors' Practice}

\section{A. Systematization of Practical Teaching System of}

\section{Finance Major}

Practical Teaching Finance should be located in the culture and improve the overall quality of students, by allowing students to acquire more knowledge and learning skills, improve problem solving skills to analyze problems, practical teaching system of finance, integration will be the future for some time important direction of development finance practice teaching in higher vocational. So, to finance vocational practice systematic teaching from a development perspective to look at, at different levels and categories should actively promote the teaching, and to keep the system convergence, it cannot be confined to one or two aspects, in the actual operation of the process, to effectively organize the various subsystems to play its overall maximum effect.

\section{B. Practical Teaching Design should Integrate \\ Characteristics of the Demand in Financial \\ Development}

At present, with the accelerating pace of social development, the financial industry is also undergoing tremendous changes, the rate of change is very rapid, and the purpose of vocational practical teaching of finance is hoping to be practical under actual working conditions the operation, to improve students' professional skills and professional competencies. Therefore, the current finance vocational practical teaching design must change the pace of development should be closely integrated financial situation in the industry to be targeted teaching guide, the preparation of teaching requirements, which is the basic requirement for financial practical teaching. If not able to do this, it will cause a theory from the actual situation, which lost the original meaning of the design of practical teaching.

\section{DEVELOPMENT DiRECTION OF FINANCE MAJOR}

\section{A. Cultivation Target and Positioning}

Positioning of colleges and universities will influence the construction and development of the cause of higher education, and fuzzy positioning of colleges and universities will cause the school to have wrong development strategies. First, colleges and universities will go through up and downs in teaching, scientific researches and guarantee. In a certain period of time, much or too little investment in one aspect of the resources, reducing the efficiency in the use of resources by teaching and scientific research and protection of investment of ups and downs, dilution of the already scarce education resources. Second, professional and talent cultivation structure adjustment asymmetry, bullish on the prospects of employment of professional regardless of their own conditions how they work fast, the creation of popular professional, resulting in convergence of professional structure, resulting in a waste of education resources investment, resulting in a new structural contradiction of employment. So the University for its own financial discipline should have a certain position and goals.

\section{B. Cultivation Paths and Roles}

Positioning is the premise and basis of the strategy. Many western universities have received the influence of pragmatism and utilitarianism in the postwar period. The aim is to make the students better adapt to the society and to master the ability. Foreign business schools pay more attention to its characteristics and advantages, and to 
analyze and summarize the training objectives and positioning of foreign famous universities and their business schools:

Firstly, Positioning of clear hierarchy;

Secondly, Positioning of clear subjects;

Thirdly, Positioning of Types;

Fourth, Positioning of Regional Advantages

\section{CONCLUSION}

In China, with the constant deepening of reform and gradually publicizing of higher education, education environmental is gradually becoming internationalized, so it is necessary for colleges and universities to explore modes to cultivate talents, which is like that China' $\mathrm{s}$ economic growth cannot mainly depend on investment and export, but it is necessary to transfer the economic growth mode. For technological innovation, the demands of industrial upgrading will eventually be implemented to the needs of the talents, and the cultivation of talents is based on the training mode of the universities and colleges Therefore, this paper is based on the reality of the problem, the discussion focused on the professional content, but not limited to professional, the use of empirical methods in the international talent in the study of Ideological and political education, and proposed to focus on the development of the Shanghai International Studies University.

The structure of this paper is reasonable, the contents of the content according to the overall structure, the level is clear, the proposed point of view is more close to the actual problem, although the article focus on empirical analysis and put forward their own point of view, but also to strengthen the theoretical depth, I also realized that their theoretical knowledge need to enrich, also hope that in the future study and life can be more open their own vision, enhance their own quality.

\section{REFERENCES}

[1] Porta, Rafael La, et al. Law and Finance. Corporate Governance. Springer Berlin Heidelberg, 2001:26-68.

[2] Laporta, Rafael, et al. "Law and Finance." Harvard Institute of Economic Research Working Papers 106.6(1996):26-68.

[3] Porta, L., F., L. R., Shleifer, A., Vishny, R., Porta, L., \& Shleifer, A., et al. (1997). Legal determinants of external finance? journal of finance. Social Science Electronic Publishing, volume 52(3), 1131-1150(20)

[4] Petersen M A. Estimating Standard Errors in Finance Panel Data Sets[J]. Review of Financial Studies, 2009, 22(1):435-480.

[5] Berger, Allen N., and G. F. Udell. "The Economics of Small Business Finance: The Role of Private Equity and Debt Markets in the Financial Growth Cycle." Journal of Banking \& Finance 22.6(1998):613-673.

[6] Mantegna, Rosario N., and H. E. Stanley. "An Introduction to Econophysics: Correlations and Complexity in Finance." Physics Today 136.3(2000):570-571.

[7] Mackinlay, A. Craig. "Event Studies in Economics and Finance." General Information 35.1(1997):13-39.

[8] Mantegna, Rosario N., and H. E. Stanley. An introduction to econophysics : correlations and complexity in finance. Cambridge University Press, 2000:570-571.

[9] King, Robert G., and R. Levine. "Finance, entrepreneurship and growth: Theory and evidence." Journal of Monetary Economics 32.3(1993):513-542.

[10] Ricciardi, Victor. "A Survey of Behavioral Finance." Social Science Electronic Publishing 1.03(2002):1053-1128.

[11] Maksimovic, Vojislav, and A. Demirgüç-Kunt. "Law, Finance And Firm Growth." Journal of Finance 53.6(1998):págs. 2107-2137.

[12] Shleifer, Andrei. "Inefficient Markets: An Introduction To Behavioral Finance." Journal of Institutional \& Theoretical Economics Jite 158.03(2002):369-374(6). 